J. Dairy Sci. 95:6591-6605

http://dx.doi.org/10.3168/jds.2012-5377

(C) American Dairy Science Association ${ }^{\circledR}, 2012$.

\title{
Effects of Saccharomyces cerevisiae fermentation product on ruminal starch digestion are dependent upon dry matter intake for lactating cows
}

\author{
M. S. Allen ${ }^{1}$ and Y. Ying \\ Department of Animal Science, Michigan State University, East Lansing 48824-1225
}

\begin{abstract}
This experiment was conducted to evaluate ruminal digestion responses to Saccharomyces cerevisiae fermentation product (SCFP) supplementation and to determine if responses are influenced by voluntary feed intake. Fifteen ruminally and duodenally cannulated Holstein cows with a wide range in preliminary dry matter intake (pDMI; 20.1 to $31.0 \mathrm{~kg} / \mathrm{d}$ ) measured during a 14-d preliminary period were used in a crossover design experiment. Treatments were SCFP and control (a mix of dry ground corn and soybean meal), topdressed at the rate of $56 \mathrm{~g} / \mathrm{d}$ per head. The base diet contained $28 \% \mathrm{NDF}, 30 \%$ starch, and $16.5 \% \mathrm{CP}$ and included corn silage, alfalfa silage, high-moisture corn, protein supplement, and a mineral and vitamin supplement. Treatment periods were $28 \mathrm{~d}$, with the final 8 d used for sample and data collection. Voluntary dry matter intake was determined during the last $4 \mathrm{~d}$ of the preliminary period. Ruminal digestion kinetics were determined using the pool-and-flux method. Main effects of SCFP treatment and their interaction with pDMI were tested by ANOVA. An interaction was detected between SCFP treatment and pDMI for ruminal digestion rate of starch; SCFP increased the rate of starch digestion compared with the control for cows with pDMI below $26 \mathrm{~kg} / \mathrm{d}$ and decreased it for cows with higher pDMI. This resulted in an interaction between treatment and $\mathrm{pDMI}$ for turnover rate of starch in the rumen and true and apparent ruminal starch digestibility because passage rate of starch from the rumen was not affected by treatment $($ mean $=24.3 \% / \mathrm{h})$. Ruminal $\mathrm{pH}($ mean $=6.0)$, dry matter intake, milk yield and component percentages were not affected by treatment or its interaction with pDMI. Supplementation of SCFP reduced the rate of ruminal starch digestion for cows with higher feed intake, which could help stabilize the ruminal environment when large amounts of starch are consumed to support higher milk production.
\end{abstract}

Received January 24, 2012.

Accepted May 25, 2012.

${ }^{1}$ Corresponding author: allenm@msu.edu
Key words: yeast culture, ruminal starch digestion, dry matter intake, digestion kinetics

\section{INTRODUCTION}

Saccharomyces cerevisiae fermentation product (SCFP, residual yeast cells, fermentation metabolites, and growth media) has been supplemented in dairy cow diets for decades to benefit ruminal fermentation and productive performance. A recent meta-analysis (Rabiee et al., 2008) indicated positive productive performance with SCFP. The soluble growth factors in SCFP have been shown to stimulate growth of pure cultures of ruminal bacteria that digest cellulose and utilize lactate in vitro (Callaway and Martin, 1997). Supplementing growth factors, such as organic acids, $\mathrm{B}$ vitamins, and AA, might shift microbial populations in the rumen, providing greater benefits under some conditions compared with others.

The mechanism(s) of action of SCFP have not been clearly established. Specific hypotheses by which SCFP benefit production include (1) stimulating growth of fiber-digesting bacteria (Callaway and Martin, 1997), thus increasing digestibility and clearance of fiber from the rumen and possibly DMI; (2) stimulating growth of lactic acid bacteria, thus decreasing accumulation of lactate (Nisbet and Martin, 1991); and (3) increasing microbial protein flow to the duodenum (Yoon and Stern, 1996; Hristov et al., 2010). In addition, SCFP tended to increase amylase concentration in the rumen (Hristov et al., 2010) and increased ruminal starch digestibility might improve milk yield in some cases.

We recently conducted an experiment to evaluate effects of SCFP on animal responses to a fermentable carbohydrate challenge (Longuski et al., 2009). The SCFP treatment increased yields of milk fat and 3.5\% FCM compared with the control treatment during the fermentable starch challenge but no treatment differences were observed for these variables when the less fermentable diet was fed. The interaction with ruminal starch fermentability indicates a likely effect on ruminal fermentation.

Inconsistent responses for SCFP treatment among experiments might be because SCFP has different 
Table 1. Characterization of 15 cows during the final $4 \mathrm{~d}$ of the 14-d preliminary period, when cows were fed a common diet

\begin{tabular}{lcccc}
\hline Parameter & Mean & SD & Minimum & Maximum \\
\hline Parity & 3.2 & 0.9 & 2 & 5 \\
BW, $^{1} \mathrm{~kg}$ & 598 & 47 & 526 & 695 \\
BCS & 2.38 & 0.51 & 1.75 & 3.50 \\
DIM & 169 & 84 & 65 & 368 \\
Milk, kg/d & 41.1 & 11.4 & 19.2 & 58.3 \\
$3.5 \% \mathrm{FCM}, \mathrm{kg} / \mathrm{d}$ & 40.6 & 9.2 & 20.0 & 51.4 \\
DMI, kg/d & 25.1 & 2.8 & 20.1 & 31.0 \\
\hline
\end{tabular}

${ }^{1}$ Rumen-empty BW.

effects for cows varying in DMI and milk yield. We have previously reported that intake, digestion, and production response to various dietary treatments is dependent upon DMI (Voelker-Linton and Allen, 2008) and milk yield (Oba and Allen, 1999a; Bradford and Allen, 2004) of cows. Erasmus et al. (2005) reported that DMI response to SCFP supplementation was dependent upon DMI of cows, with a reduction in DMI for cows consuming less than, and an increase in DMI for cows consuming more than $23.8 \mathrm{~kg}$ of $\mathrm{DM} / \mathrm{d}$. Our objective was to evaluate the effects of SCFP on ruminal fermentation using cows with a wide range in DMI. We hypothesized that effects of SCFP on ruminal fermentation of carbohydrates depended upon DMI of lactating cows.

\section{MATERIALS AND METHODS}

\section{Cows, Treatments, and Diets}

Experimental procedures were approved by the Institutional Animal Care and Use Committee at Michigan State University (East Lansing). Sixteen multiparous Holstein cows from the Michigan State University Dairy Cattle Teaching and Research Center were assigned randomly to treatment sequence in a crossover design experiment with one 14-d preliminary period and two 28-d experimental periods. Cows were cannulated ruminally and duodenally before calving. Surgery was performed at the Department of Large Animal Clinical Science, College of Veterinary Medicine, Michigan State University. These cows were $169 \pm 84$ (mean \pm SD) DIM at the end of the preliminary period and were selected to provide a wide range and uniform distribution of DMI and milk yield. One cow was removed from the study on d 20 of the first period because of a malfunctioning duodenal cannula that impaired flow. The status of 15 cows during the final $4 \mathrm{~d}$ of the 14-d preliminary period is reported in Table 1; DMI ranged among cows from 20.1 to $31.0 \mathrm{~kg} / \mathrm{d}($ mean $=25.1 \mathrm{~kg} / \mathrm{d}$ ) and $3.5 \%$ FCM yield ranged from 20.0 to $51.4 \mathrm{~kg} / \mathrm{d}$ $($ mean $=40.6 \mathrm{~kg} / \mathrm{d})$.
Throughout the experiment, cows were housed in tiestalls. Treatment sequence was alternately assigned to stalls and cows were then randomly assigned to stalls and, therefore, treatment sequence. Treatments were Diamond V XP Yeast Culture (SCFP; Diamond V Mills Inc., Cedar Rapids, IA) and a mix of dry, finely ground shelled corn and soybean meal (control, CON). Prior to the experiment, treatments were weighed to within one-tenth of a gram to the target weight of $56.0 \mathrm{~g}$ and individually stored in air-tight bags. Treatments were top-dressed daily and partially mixed into the TMR in the feed manger.

Cows were moved to an exercise lot twice daily (0230 and $1330 \mathrm{~h}$ ) before milking in a parlor (0400 and 1500 h). Stalls were equipped with lock-out devices that were manually closed when cows were away from stalls for exercise and milking and during feeding. Orts were removed and weighed at $1000 \mathrm{~h}$, after which base diets were delivered to individual stalls, treatments were topdressed, and feed doors were reopened at $1130 \mathrm{~h}$. Water was available ad libitum throughout each day via individual water cups in each stall and in the exercise lot. Cows had access to feed for approximately $19 \mathrm{~h}$ per day.

The common base diet contained corn silage $(67 \%$ of forage DM), alfalfa silage (33\% of forage DM), highmoisture corn, SoyPLUS (West Central Soy, Ralston, IA), soybean meal 48, limestone, and a premix of minerals and vitamins. The base diet was formulated for $28 \%$ NDF and $17 \%$ CP. Forage samples were collected twice weekly and analyzed to adjust diets to account for DM, NDF, and CP fluctuation. Ingredients and nutrient composition of the experimental diets are shown in Table 2.

\section{Data and Sample Collection}

Diets were fed as TMR once daily at $110 \%$ of expected intake. The amount of feed offered and refused (orts) was weighed daily for each cow. Samples of all dietary ingredients $(0.5 \mathrm{~kg})$ and orts $(12.5 \%)$ were collected daily from d 11 to 14 during the preliminary period and d 21 to 25 during each experimental period. 
Table 2. Ingredients and chemical composition of the ration (as analyzed)

\begin{tabular}{lc}
\hline Composition & Value \\
\hline Ingredient, \% of DM & \\
Corn silage & 37.1 \\
High-moisture corn & 23.5 \\
Alfalfa silage & 18.6 \\
Soybean meal (48\% CP) & 10.8 \\
SoyPLUS ${ }^{1}$ & 5.0 \\
Vitamin mineral mix ${ }^{2}$ & 4.0 \\
Limestone & 1.0 \\
Chemical composition & \\
DM, \% & 49.6 \\
OM, \% of DM & 92.6 \\
NDF, \% of DM & 28.0 \\
\% of forage NDF & 23.6 \\
\% of NDF from forage & 84.3 \\
iNDF, \% of DM & 11.6 \\
iNDF, \% of NDF & 41.4 \\
CP, \% of DM & 16.5 \\
Starch, \% of DM & 30.1 \\
\hline
\end{tabular}

${ }^{1}$ West Central Soy (Ralston, IA).

${ }^{2}$ Vitamin mineral mix contained (DM basis) $17.6 \%$ sodium bicarbonate, $15.1 \%$ magnesium sulfate, $7.5 \%$ salt, $6.0 \%$ dicalcium phosphate, $2.5 \%$ trace mineral premix, $0.4 \%$ vitamin $\mathrm{A}, 0.4 \%$ vitamin $\mathrm{D}, 0.2 \%$ vitamin $\mathrm{E}$, and $50.2 \%$ dry ground corn as a carrier.

${ }^{3}$ Indigestible NDF.

Samples were frozen immediately after collection at $-20^{\circ} \mathrm{C}$ and combined to 1 composite sample per period before analysis.

Milk yield was measured and milk was sampled at each milking on d 11 to 14 of the preliminary period and on d 21 to 25 of the experimental periods. Two milk samples were taken at each milking on collection days from each cow; 1 sample was analyzed for fat, true protein, lactose, and SCC and the other was analyzed for FA profile. Rumen-empty BW was measured after evacuation of ruminal digesta on d 14 of the preliminary period and d 28 of each experimental period. Body condition score was determined on the same days as BW by 4 trained investigators blinded to treatments (Wildman et al., 1982; 5-point scale, where $1=$ thin and $5=$ fat).

Chromic oxide was used as a marker to calculate fecal output to determine total-tract digestibility. Gelatin capsules (1.5 oz.; Tropac Inc., Airfield, NJ) containing $5 \mathrm{~g}$ of chromic oxide and ground spelt hulls (Wiley mill, 2-mm screen; Arthur H. Thomas Co., Philadelphia, PA) were dosed through the ruminal cannula at 0730 , 1530 , and $2330 \mathrm{~h}$ (total of $15 \mathrm{~g}$ of $\mathrm{Cr}_{2} \mathrm{O}_{3} / \mathrm{d}$ ) from 14 to $25 \mathrm{~d}$ with a priming dose of $2 \times$ on $\mathrm{d} 14$. Duodenal samples $(1,000 \mathrm{~mL})$, fecal samples $(500 \mathrm{~g})$, ruminal digesta samples for microbial isolation $(1,000 \mathrm{~mL})$, and rumen fluid samples for $\mathrm{pH}$ and concentrations of VFA, lactate, and ammonia $(100 \mathrm{~mL})$ were collected every $15 \mathrm{~h}$ from d 21 to 25 of each experimental period so that 8 samples were taken for each cow in each period, representing every $3 \mathrm{~h}$ of a 24 -h period to account for diurnal variation. For microbial isolation, rumen fluid and particulate phase samples were collected from the reticulum near the reticular-omasal orifice, transported to the laboratory, and processed immediately after collection. Ruminal digesta were blended for $30 \mathrm{~s}$ and filtered through 1 layer of nylon screen. The sample was centrifuged at $500 \times g$ for $15 \mathrm{~min}$. The supernatant was centrifuged at $9,000 \times g$ for $15 \mathrm{~min}$ and the pellet was washed with $0.9 \% \mathrm{NaCl}$ and centrifuged at 18,000 $\times g$ for $15 \mathrm{~min}$. The pellet was resuspended with a small amount of distilled water and frozen at $-20^{\circ} \mathrm{C}$. Rumen fluid for $\mathrm{pH}$, VFA, lactate, and ammonia was obtained by combining digesta from 5 different sites in the rumen and straining it through nylon mesh; fluid $\mathrm{pH}$ was recorded immediately and samples were stored at $-20^{\circ} \mathrm{C}$.

Feeding and ruminating behavior was observed for $24 \mathrm{~h}$ on d 26 of each treatment period. Cow activities were manually recorded in real time every 5 min. Meal frequency, intermeal interval, ruminating bouts, and time were determined using Igor Pro Carbon (version 4.07; WaveMetrics Inc., Lake Oswego, OR).

Ruminal contents were evacuated manually through the ruminal cannula at $1530 \mathrm{~h}$ ( $4.5 \mathrm{~h}$ after feeding) on d 27 and $42 \mathrm{~h}$ later at $0930 \mathrm{~h}$ ( $2 \mathrm{~h}$ before feeding) on d 28 of each experimental period (days in this experiment began at $1130 \mathrm{~h}$ ). Total rumen content mass and volume were determined. To ensure accurate sampling, every tenth handful of digesta $(10 \%)$ was separated for a subsample throughout evacuation. This subsample was squeezed into primarily solid and liquid phases. Both phases were weighed and sampled $(350 \mathrm{~mL})$ for determination of nutrient pool size. All samples were stored at $-20^{\circ} \mathrm{C}$.

\section{Sample Analysis and Calculations}

Milk yield recorded at both milkings were summed for a daily total, which were averaged for each period. Milk samples were analyzed for fat, true protein, lactose, and SNF concentrations, as well as SCC with infrared spectroscopy (AOAC, 1990) by Universal Labs (East Lansing, MI).

Forages and orts were ground with dry ice in a Wiley mill (6-mm screen), subsampled, and lyophilized (Tri-Philizer MP; FTS Systems Inc., Stone Ridge, NY) for analysis of DM concentration. Dried forage and orts were reground in a Wiley mill (1-mm screen). Concentrates were ground in a cyclone mill (2-mm screen, Udy Mill; Seedburo Equipment Co., Chicago, IL). Frozen duodenal samples for each cow period (n $=8$ ) were finely chopped using a commercial food processor (84142 Food cutter; Hobart Manufacturing 
Co., Troy, $\mathrm{OH}$ ) and subsampled in the frozen state to obtain representative samples. Duodenal, ruminal, and fecal samples for nutrient and chromium determination were lyophilized (Tri-Philizer MP; FTS Systems Inc.) and ground as above. Dried ruminal solid and liquid samples obtained by rumen emptying were recombined according to their original ratio. Dried, ground duodenal and fecal samples were combined on an equal DM basis into 1 sample per cow per period.

Samples were analyzed for DM, ash, NDF, indigestible NDF (iNDF), ADF, ADL, CP, starch, and gross energy (GE). Ash concentration was determined after $5 \mathrm{~h}$ combustion at $550^{\circ} \mathrm{C}$ in a muffle furnace. Concentrations of NDF were determined according to Mertens (2002) and ADF and ADL according to Goering and Van Soest (1970). Indigestible NDF was estimated as NDF residue after 240-h in vitro fermentation (Goering and Van Soest, 1970); flasks were reinoculated at $120 \mathrm{~h}$ to ensure a viable microbial population. Ruminal fluid for the in vitro incubations was collected from a nonpregnant dry cow fed dry hay only. The fraction of potentially digestible NDF (pdNDF) was calculated by difference $(1.00-\mathrm{iNDF})$. Crude protein was analyzed according to Hach et al. (1987). Starch was measured by an enzymatic method (Karkalas, 1985) after samples were gelatinized with sodium hydroxide. Glucose concentration was measured using a glucose oxidase method (PGO enzyme product no. P7119; Sigma Chemical Co., St. Louis, MO), and absorbance was determined with a microplate reader (SpectraMax 190; Molecular Devices Corp., Sunnyvale, CA). Gross energy was assayed by bomb calorimeter (Parr Instrument Inc., Moline, IL). Concentrations of all nutrients except DM were expressed as percentages of DM determined by drying at $105^{\circ} \mathrm{C}$ in a forced-air oven for $8 \mathrm{~h}$.

Purine concentration was used as a microbial marker to determine the flow of microbial N, OM, and starch to the duodenum. Microbial pellets obtained by differential centrifugation of ruminal digesta proximal to the ruminoreticular orifice (described above) were ground with a mortar and pestle and analyzed for $\mathrm{CP}$, ash, and starch as described above. Microbial pellets and duodenal digesta were analyzed for total purines by spectrophotometer (Beckman Instruments Inc., Fullerton, CA) at $260 \mathrm{~nm}$ according to Zinn and Owens (1986). Ammonia concentration was determined for centrifuged duodenal samples according to Broderick and Kang (1980) to estimate NAN and nonammonia, nonmicrobial N (NANMN) flow to the duodenum. Rumen fluid was also analyzed for ammonia concentration and concentration of major VFA and lactate were analyzed by HPLC (Waters Corp., Milford, MA) according to Weimer et al. (1999).
Diet ingredients, duodenal digesta, and feces were analyzed for concentrations of chromium. Samples were digested with phosphoric acid (Williams et al., 1962), and chromium was quantified by flame atomic absorption spectrometry (SpectraAA 220; Varian, Victoria, Australia) according to the manufacturer's specifications. Duodenal flux was calculated for DM, OM, iNDF, pdNDF, starch, microbial N, NANMN, and ammonia $\mathrm{N}$, using acid detergent sulfuric acid lignin as a flow marker (Cochran et al., 1986). Duodenal flow of microbial OM was determined using the ratio of purines to OM (Oba and Allen, 2003c), and true ruminally degraded $\mathrm{OM}$ was calculated by subtracting duodenal flow of nonmicrobial OM from OM intake. Ruminal pool sizes (kg) of OM, NDF, iNDF, pdNDF, starch, microbial N, and NMNAN were determined by multiplying the concentration of each component in rumen samples by the ruminal digesta DM mass $(\mathrm{kg})$. Dry matter and nutrient intakes were calculated using the composition of feed offered and refused. Ruminal digestibility was determined for each fraction. Turnover rate in the rumen, passage rate from the rumen, and ruminal digestion rate of each component were calculated by the pool-and-flux method according to Oba and Allen (2003b). Yield of milk and milk components, milk composition, and changes in empty BW and BCS were calculated. Preliminary dry matter intake (pDMI) was calculated as the mean DMI on d 11 to 14 of the 14-d preliminary period.

Milk samples were composited based on milk fat yield and centrifuged at $17,800 \times g$ for $30 \mathrm{~min}$ at $8^{\circ} \mathrm{C}$. Fat cake (300-400 mg) was extracted according to Hara and Radin (1978) and methyl esters were formed according to Christie (1982) as modified by Chouinard et al. (1999). Fatty acids were quantified by GC (model 8500; PerkinElmer Corp., Norwalk, CT), using a SP2560 capillary column $(100-\mathrm{m} \times 0.20-\mathrm{mm}$ i.d. with $0.02-\mu \mathrm{m}$ film thickness; Supelco Inc., Bellefonte, PA). The oven temperature was $140^{\circ} \mathrm{C}$ for $5 \mathrm{~min}$, and was then ramped up $4^{\circ} \mathrm{C} / \mathrm{min}$ to $240^{\circ} \mathrm{C}$ and held for $15 \mathrm{~min}$. The helium flow was $20 \mathrm{~cm} / \mathrm{sec}$.

Energy values were calculated as follows:

$$
\begin{gathered}
\text { Digestible energy }(\mathrm{DE}) \text { intake }=\text { GE intake } \\
\times \text { GE digestibility }
\end{gathered}
$$

the $\mathrm{NE}_{\mathrm{L}}$ intake was calculated from $\mathrm{DE}$ through $\mathrm{ME}$ according to NRC (2001);

$$
\begin{gathered}
\text { Milk } \mathrm{NE}_{\mathrm{L}}(\mathrm{Mcal} / \mathrm{d})=\mathrm{MY}(\mathrm{kg}) \times[0.0929 \times(\text { fat \% }) \\
+0.0563 \times(\text { true protein } \%)+0.0395 \\
\times(\text { lactose } \%)](\mathrm{NRC}, 2001)
\end{gathered}
$$


Table 3. Milk production and composition, feed intake, and BW change of cows for Saccharomyces cerevisiae fermentation product (SCFP) and control $(\mathrm{CON})$ treatments and interaction with DMI measured during the preliminary period

\begin{tabular}{|c|c|c|c|c|c|c|c|c|c|}
\hline \multirow[b]{2}{*}{ Item } & \multicolumn{2}{|c|}{ Treatment LSM } & \multirow[b]{2}{*}{$\mathrm{SE}$} & \multicolumn{6}{|c|}{$P$-value ${ }^{1}$} \\
\hline & $\mathrm{CON}$ & SCFP & & Trt & $\begin{array}{l}\text { Trt } \times \\
\text { period }\end{array}$ & $\mathrm{pDMI}$ & $\begin{array}{l}\text { Trt } \times \\
\text { pDMI }\end{array}$ & $\begin{array}{c}\mathrm{pDMI} \times \\
\mathrm{pDMI}\end{array}$ & $\begin{array}{c}\text { Trt } \times \text { pDMI } \\
\times \text { pDMI }\end{array}$ \\
\hline \multicolumn{10}{|l|}{ Yield, kg/d } \\
\hline Milk & 36.1 & 36.5 & 3.0 & 0.64 & $\mathrm{NS}^{2}$ & NS & NS & NS & NS \\
\hline $\mathrm{FCM}(3.5 \%)$ & 34.8 & 36.1 & 2.5 & 0.16 & NS & 0.01 & NS & NS & NS \\
\hline Milk fat & 1.19 & 1.26 & 0.09 & 0.11 & NS & 0.01 & NS & NS & NS \\
\hline SNF & 1.97 & 2.00 & 0.19 & 0.65 & NS & 0.05 & NS & NS & NS \\
\hline \multicolumn{10}{|l|}{ Milk composition, \% } \\
\hline Fat & 3.49 & 3.59 & 0.24 & 0.28 & NS & NS & NS & NS & NS \\
\hline Protein & 3.14 & 3.16 & 0.09 & 0.70 & NS & NS & NS & NS & NS \\
\hline Lactose & 4.52 & 4.53 & 0.01 & 0.81 & NS & 0.04 & NS & NS & NS \\
\hline SNF & 5.37 & 5.37 & 0.13 & 0.88 & NS & 0.05 & NS & NS & NS \\
\hline MUN, mg/dL & 11.8 & 12.3 & 0.37 & 0.21 & NS & NS & NS & NS & NS \\
\hline
\end{tabular}

${ }^{1} P$-values for treatment (Trt), Trt by period interaction (Trt $\times$ period), preliminary DMI (pDMI), Trt by pDMI interaction $($ Trt $\times$ pDMI), quadratic effect of $\mathrm{pDMI}(\mathrm{pDMI} \times \mathrm{pDMI})$, and Trt by quadratic effect of $\mathrm{pDMI}($ Trt $\times \mathrm{pDMI} \times \mathrm{pDMI})$.

${ }^{2} \mathrm{NS}=$ nonsignificant, with $P>0.15$; term was removed from the statistical model. Linear and quadratic effects of pDMI were removed from the model if their corresponding interactions with Trt were removed, although $P$-values are included in the table.

${ }^{3}$ Determined using $55^{\circ} \mathrm{C}$ DM.

the $\mathrm{NE}_{\mathrm{L}} \mathrm{BW}$ gain was calculated according to $\mathrm{NRC}$ (2001); and

$\mathrm{NE}_{\mathrm{L}}$ available for maintenance $=\mathrm{NE}_{\mathrm{L}}$ intake

$-\mathrm{NE}_{\mathrm{L}}$ milk $-\mathrm{NE}_{\mathrm{L}} \mathrm{BW}$ gain.

\section{Statistical Analysis}

All data were analyzed by using the fit model procedure of JMP (version 8; SAS Institute Inc., Cary, NC). To determine differences between treatments and evaluate interactions of treatment with DMI, where pDMI (calculated as the mean of DMI values on d 11 to 14 of

Table 4. Rumen pools of cows for Saccharomyces cerevisiae fermentation product (SCFP) and control (CON) treatments and interaction with DMI measured during the preliminary period

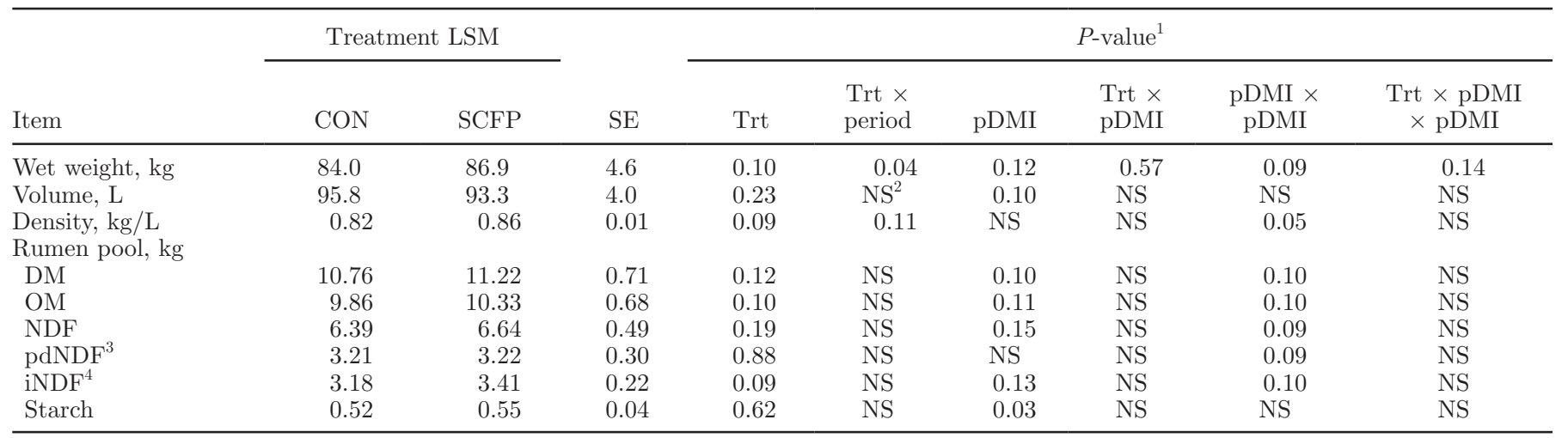

${ }^{1} P$-values for treatment (Trt), Trt by period interaction (Trt $\times$ period), preliminary DMI $(\mathrm{pDMI})$, Trt by pDMI interaction $($ Trt $\times$ pDMI), quadratic effect of pDMI $(\mathrm{pDMI} \times \mathrm{pDMI})$, and Trt by quadratic effect of pDMI $($ Trt $\times \mathrm{pDMI} \times \mathrm{pDMI})$.

${ }^{2} \mathrm{NS}=$ nonsignificant, with $P>0.15$; term was removed from the statistical model. Linear and quadratic effects of pDMI were removed from the model if their corresponding interactions with Trt were removed, although $P$-values are included in the table.

${ }^{3} \mathrm{pdNDF}=$ potentially digestible NDF.

${ }^{4} \mathrm{iNDF}=$ indigestible NDF. 
Table 5. Feeding behavior and chewing activity of cows for Saccharomyces cerevisiae fermentation product (SCFP) and control (CON) treatments and interaction with DMI measured during the preliminary period

\begin{tabular}{|c|c|c|c|c|c|c|c|c|c|}
\hline \multirow[b]{2}{*}{ Item } & \multicolumn{2}{|c|}{ Treatment LSM } & \multirow[b]{2}{*}{$\mathrm{SE}$} & \multicolumn{6}{|c|}{$P$-value ${ }^{1}$} \\
\hline & $\mathrm{CON}$ & SCFP & & Trt & $\begin{array}{l}\text { Trt } \times \\
\text { period }\end{array}$ & $\mathrm{pDMI}$ & $\begin{array}{l}\text { Trt } \times \\
\text { pDMI }\end{array}$ & $\begin{array}{c}\mathrm{pDMI} \times \\
\mathrm{pDMI}\end{array}$ & $\begin{array}{c}\text { Trt } \times \text { pDMI } \\
\times \text { pDMI }\end{array}$ \\
\hline \multicolumn{10}{|l|}{ Meals } \\
\hline Bouts/d & 9.1 & 9.3 & 0.4 & 0.78 & $\mathrm{NS}^{2}$ & 0.12 & NS & NS & NS \\
\hline Length, $\min /$ bout & 26.7 & 26.2 & 1.5 & 0.78 & NS & NS & NS & NS & NS \\
\hline Interval, min & 147 & 141 & 7 & 0.48 & NS & 0.08 & 0.09 & NS & NS \\
\hline \multicolumn{10}{|l|}{ Rumination } \\
\hline Bouts/d & 14.6 & 14.8 & 0.6 & 0.70 & 0.06 & NS & NS & NS & NS \\
\hline Length, $\min /$ bout & 35.6 & 36.2 & 1.6 & 0.76 & NS & NS & NS & NS & NS \\
\hline Interval, min & 59.3 & 59.0 & 2.1 & 0.89 & 0.01 & NS & NS & NS & NS \\
\hline \multicolumn{10}{|l|}{ Ruminating time } \\
\hline $\operatorname{Min} / \mathrm{d}$ & 512 & 527 & 14 & 0.14 & NS & NS & NS & 0.14 & NS \\
\hline \multicolumn{10}{|l|}{ Idle time } \\
\hline
\end{tabular}

${ }^{1} P$-values for treatment (Trt), Trt by period interaction (Trt $\times$ period), preliminary DMI (pDMI), Trt by pDMI interaction $($ Trt $\times$ pDMI), quadratic effect of $\mathrm{pDMI}(\mathrm{pDMI} \times \mathrm{pDMI})$, and Trt by quadratic effect of $\mathrm{pDMI}($ Trt $\times \mathrm{pDMI} \times \mathrm{pDMI})$.

${ }^{2} \mathrm{NS}=$ nonsignificant, with $P>0.15$; term was removed from the statistical model. Linear and quadratic effects of pDMI were removed from the model if their corresponding interactions with Trt were removed, although $P$-values are included in the table.

the 14-d preliminary period) was used as the covariate for treatment responses, data were analyzed according to the following model: $\mathrm{Y}_{\mathrm{ijk}}=\mu+\mathrm{C}_{\mathrm{i}}+\mathrm{P}_{\mathrm{j}}+\mathrm{T}_{\mathrm{k}}+\mathrm{PT}_{\mathrm{jk}}$ $+\mathrm{pDMI}+\mathrm{T}_{\mathrm{k}} \mathrm{pDMI}+\mathrm{pDMI}^{2}+\mathrm{T}_{\mathrm{k}} \mathrm{pDMI}^{2}+\mathrm{e}_{\mathrm{ijk}}$, where $Y_{\mathrm{ijk}}$ is the dependent variable, $\mu$ is the overall mean, $\mathrm{C}_{\mathrm{i}}$ is the random effect of cow ( $\mathrm{i}=1$ to 15$), \mathrm{P}_{\mathrm{j}}$ is the fixed effect of period ( $\mathrm{j}=1$ to 2$), \mathrm{T}_{\mathrm{k}}$ is the fixed effect of treatment ( $\mathrm{k}=1$ to 2$), \mathrm{PT}_{\mathrm{jk}}$ is the interaction of period and treatment, $\mathrm{pDMI}$ is the linear effect of $\mathrm{pDMI}, \mathrm{T}_{\mathrm{k}} \mathrm{p}-$ DMI is the interaction of treatment and pDMI (linear), $\mathrm{pDMI}^{2}$ is the quadratic effect of $\mathrm{pDMI}, \mathrm{T}_{\mathrm{k}} \mathrm{pDMI}^{2}$ is the interaction of treatment and pDMI (quadratic), and $\mathrm{e}_{\mathrm{ijk}}$ is the residual error. Statistical significance for $\mathrm{T}_{\mathrm{k}} \mathrm{pDMI}$ and $\mathrm{T}_{\mathrm{k}} \mathrm{pDMI}{ }^{2}$ indicated that treatment differences were related to pDMI. Covariate and interaction terms were removed stepwise from the model if $P>0.15$. Linear and quadratic effects of pDMI were removed from the model if their corresponding interactions were removed. Treatment effects and their interaction (linear and quadratic relationships) were declared significant at $P \leq$ 0.05 and $P \leq 0.10$, respectively. Tendencies for treatment effects and their interactions were declared at $P$ $\leq 0.10$ and $P \leq 0.15$, respectively.

\section{RESULTS}

No main effects of treatment or interactions with pDMI were detected for DMI, yield of milk or milk components, milk composition, FCM/DMI, or change in BW or BCS (Table 3). The SCFP tended to increase the rumen pool size of iNDF and density of digesta in the rumen $(3.41$ vs. $3.18 \mathrm{~kg}$ and 0.86 vs. $0.82 \mathrm{~kg} / \mathrm{L}$, respectively; both $P<0.10$; Table 4) compared with CON and tended to interact with pDMI $(P=0.14$ quadratic) to increase pool size of wet digesta for cows

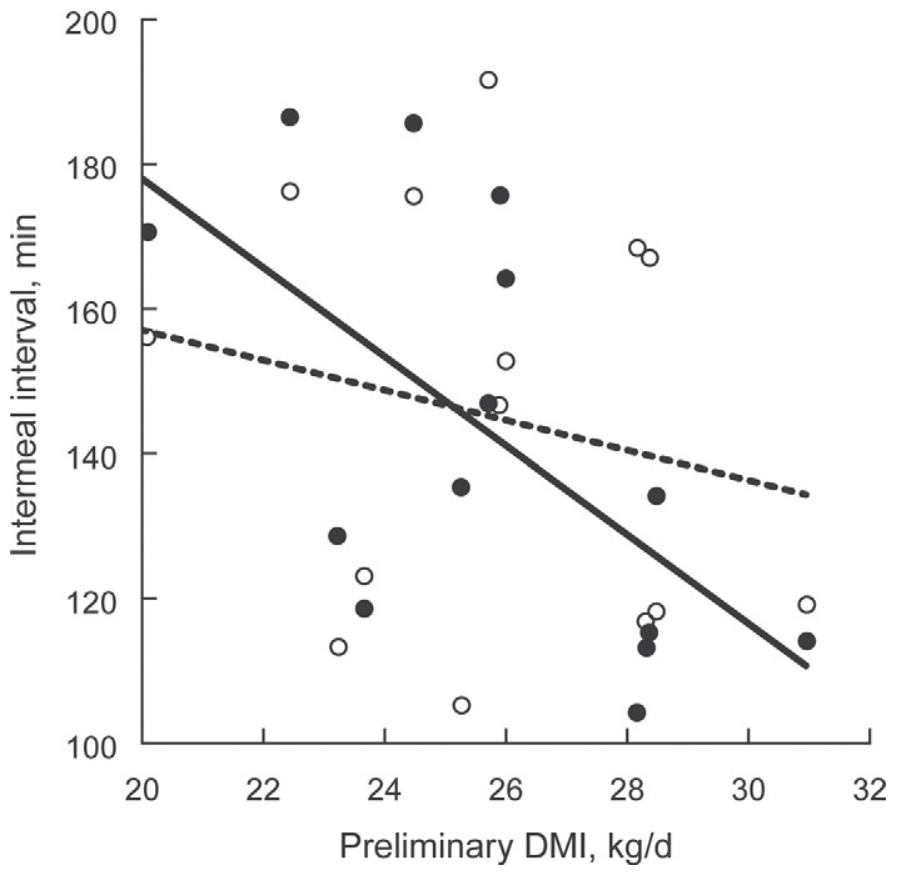

Figure 1. Interaction of control (CON; open circles, dashed line) and Saccharomyces cerevisiae fermentation product (SCFP; closed circles, solid line) with preliminary DMI (pDMI) for intermeal interval $(P=0.09$ linear $)$. The $\mathrm{pDMI}$ on the $\mathrm{x}$-axis are the mean DMI of individual cows during the final $4 \mathrm{~d}$ of the preliminary period when all cows were fed a common diet. Intermeal interval decreased linearly as pDMI increased for SCFP $(P=0.02)$ but no relationship was observed for $\operatorname{CON}(P=0.47)$. 
between approximately 23 and $30 \mathrm{~kg}$ of $\mathrm{pDMI} / \mathrm{d}$ and decrease pool size for cows outside this range. The SCFP did not affect wet weight or volume of digesta or pool sizes of DM, OM, NDF, pdNDF, or starch in the rumen compared with $\mathrm{CON}$, nor interact with $\mathrm{pDMI}$ to affect these pools. Although SCFP did not affect DMI compared with CON, it interacted with pDMI to affect intermeal interval $(P=0.09$; Table 5$)$, which was longer for cows with lower pDMI and shorter for cows with higher pDMI when offered the SCFP treatment compared with CON (Figure 1). Intermeal interval decreased linearly from approximately 180 to approximately $110 \mathrm{~min} / \mathrm{d}$ as the pDMI of cows increased from approximately 20 to $31 \mathrm{~kg} / \mathrm{d}$ for $\operatorname{SCFP}(P=0.02)$ but was not affected by pDMI for CON $(P=0.47)$. No other effects of SCFP on feeding or ruminating behavior were detected.

Flow data using $\mathrm{Cr}_{2} \mathrm{O}_{3}$ was not reasonable and we evaluated several intrinsic flow markers as an alternative, including 240-h in vitro iNDF, ADL, and peroxide ADL and ADL peroxide (Cochran et al., 1988). We obtained similar results for these markers and chose to use ADL as a flow marker.

No main effects of treatment or interactions of treatment and pDMI were detected for rumen turnover rates or times for NDF, pdNDF, or iNDF; rates of passage of pdNDF or iNDF; rate of digestion of pdNDF (Table 6); or ruminal, postruminal, or total-tract digestibility of NDF or pdNDF (Table 7). Postruminal digestibilities of pdNDF were negative because artifact pdNDF was produced postruminally or from errors in measuring flow to the duodenum; therefore, these data were omitted.

The SCFP interacted with pDMI to affect ruminal digestion rate of starch $(P<0.01$ linear; Table 6$)$; SCFP increased the rate of starch digestion compared with CON for cows with pDMI below approximately $26 \mathrm{~kg} / \mathrm{d}$ and decreased it for cows with higher pDMI (Figure 2). The digestion rate of starch in the rumen decreased linearly from approximately 50 to approximately $15 \% / \mathrm{h}$ as pDMI increased from approximately 20 to $31 \mathrm{~kg} / \mathrm{d}$ for SCFP $(P<0.01)$ but was not affected by $\mathrm{pDMI}$ for CON $(P=0.45)$. This resulted in an interaction between treatment and pDMI for turnover rate of starch in the rumen $(P=0.03$ linear; Table 6 ) and true and apparent ruminal starch digestibility $(P<0.10$ quadratic; Table 8$)$ because passage rate of starch from the rumen was not affected by treatment $($ mean $=24.3 \% / \mathrm{h}$; Table 6$)$. True and apparent ruminal starch digestibility and amount digested per day

Table 6. Rumen kinetics for Saccharomyces cerevisiae fermentation product (SCFP) and control (CON) treatments and interaction with DMI measured during the preliminary period

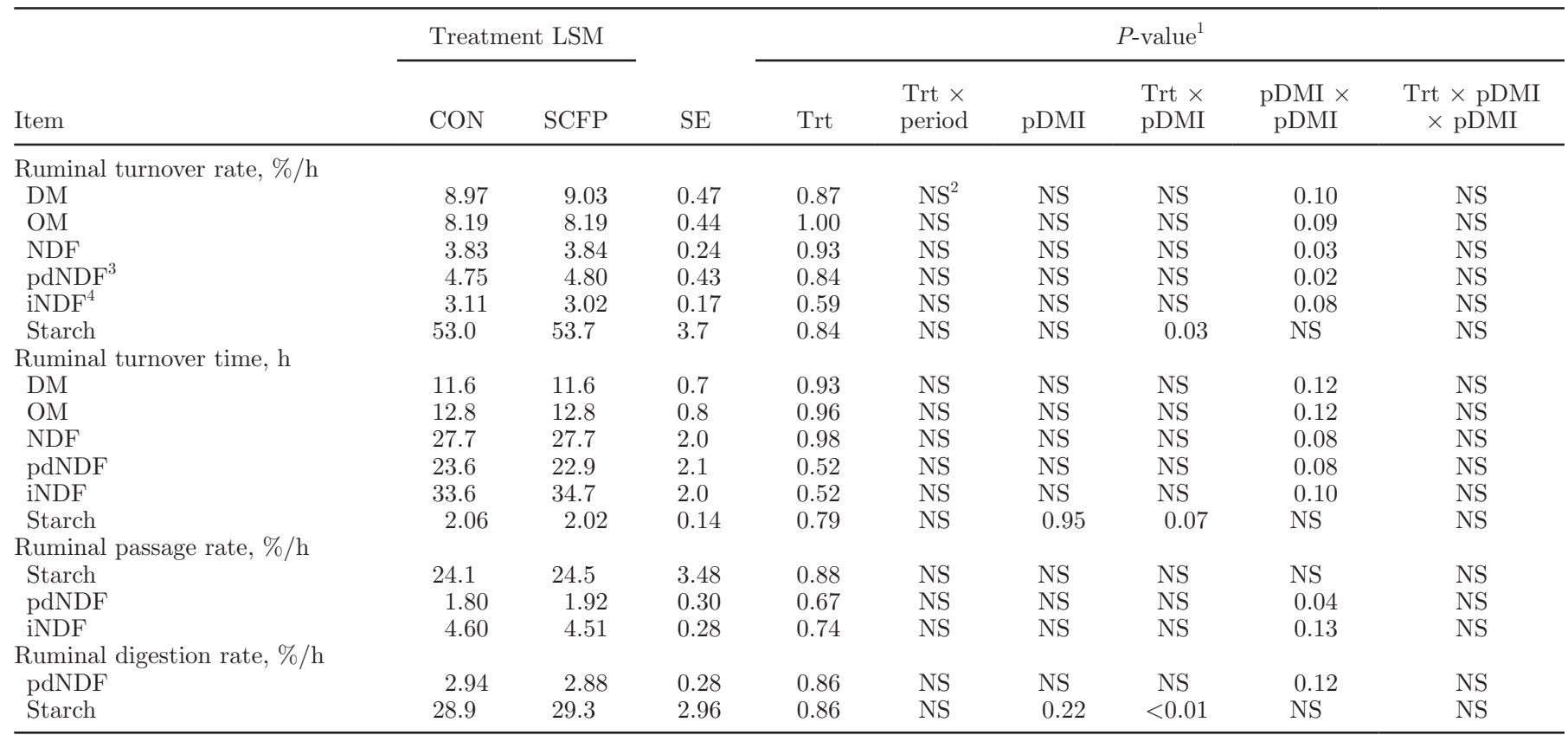

${ }^{1} P$-values for treatment (Trt), Trt by period interaction $($ Trt $\times$ period), preliminary DMI (pDMI), Trt by pDMI interaction $($ Trt $\times$ pDMI), quadratic effect of $\mathrm{pDMI}(\mathrm{pDMI} \times \mathrm{pDMI})$, and Trt by quadratic effect of $\mathrm{pDMI}($ Trt $\times \mathrm{pDMI} \times \mathrm{pDMI})$.

${ }^{2} \mathrm{NS}=$ nonsignificant, with $P>0.15$; term was removed from the statistical model. Linear and quadratic effects of pDMI were removed from the model if their corresponding interactions with Trt were removed, although $P$-values are included in the table.

${ }^{3}$ Potentially digestible NDF.

${ }^{4}$ Indigestible NDF. 
Table 7. Neutral detergent fiber digestion by cows for Saccharomyces cerevisiae fermentation product (SCFP) and control (CON) treatments and interaction with DMI measured during the preliminary period

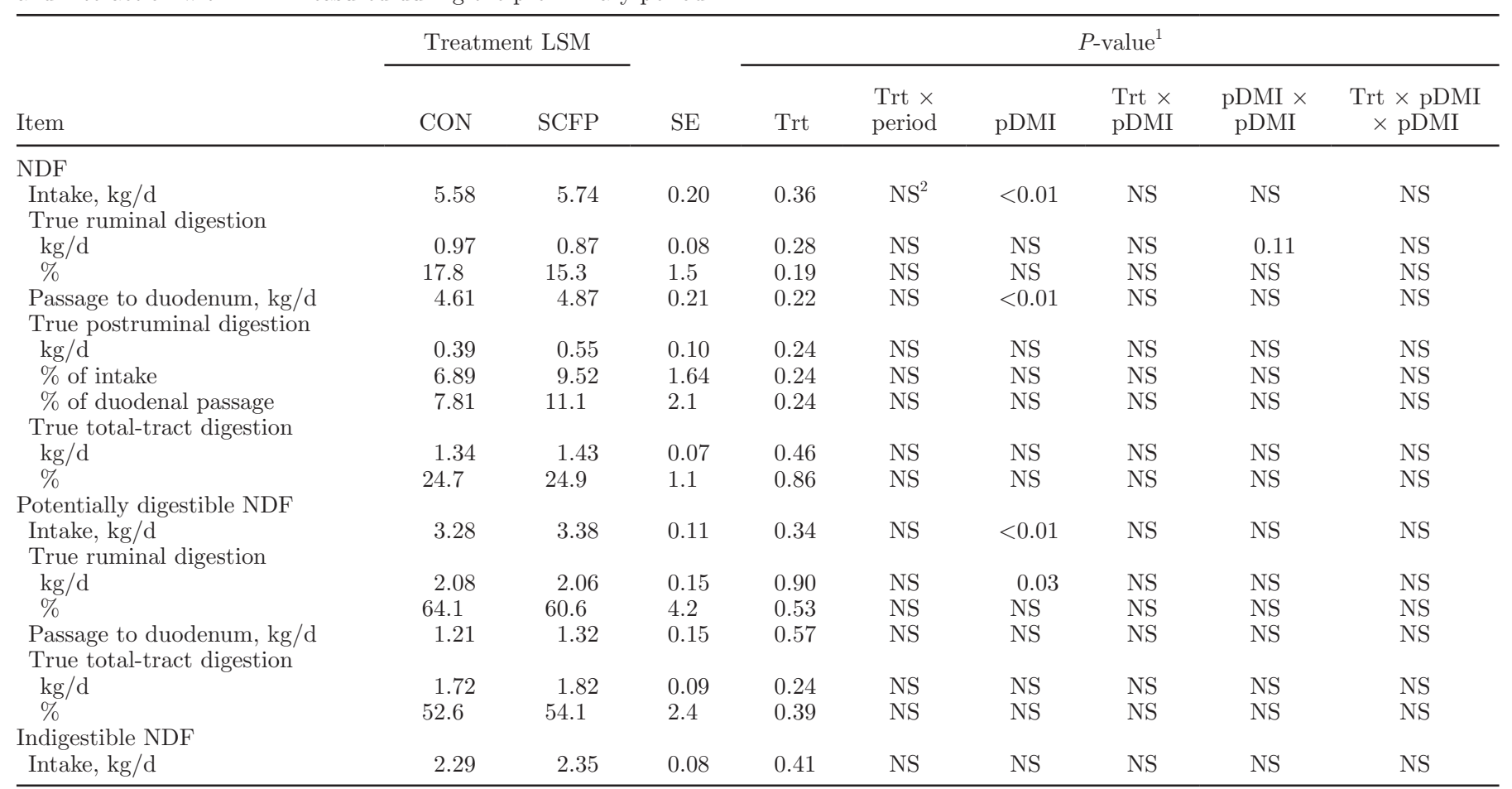

${ }^{1} P$-values for treatment (Trt), Trt by period interaction (Trt $\times$ period), preliminary DMI (pDMI), Trt by pDMI interaction $($ Trt $\times$ pDMI), quadratic effect of pDMI $(\mathrm{pDMI} \times \mathrm{pDMI})$, and Trt by quadratic effect of $\mathrm{pDMI}($ Trt $\times \mathrm{pDMI} \times \mathrm{pDMI})$.

${ }^{2} \mathrm{NS}=$ nonsignificant, with $P>0.15$; term was removed from the statistical model. Linear and quadratic effects of pDMI were removed from the model if their corresponding interactions with Trt were removed, although $P$-values are included in the table.

were increased by SCFP compared with CON for cows with lower pDMI, but decreased by SCFP compared with CON for cows with higher pDMI (interaction $P$ $<0.10$ quadratic). Starch flow to the duodenum was subsequently decreased by SCFP compared with CON for cows with lower pDMI, but increased by SCFP compared with CON for cows with higher pDMI $(P=$ 0.04 linear; Table 8). No effects of treatment or interactions with pDMI were observed for apparent totaltract starch digestion (amount or digestibility) because of compensatory starch digestion postruminally. The SCFP interacted with pDMI to affect apparent postruminal starch digestion ( $P=0.07$ quadratic) opposite to the effects on ruminal starch digestion; postruminal starch digestion (amount and percentage of intake) was decreased by SCFP compared with CON for cows with lower pDMI but increased for SCFP compared with CON for cows with higher pDMI.

The SCFP treatment interacted with pDMI to affect ruminal true and apparent digestibility of $\mathrm{OM}$ and amounts of $\mathrm{OM}$ digested per day $(P<0.08$ quadratic; Table 9). These effects were similar to those observed for ruminal digestion of starch; digestibility and amounts digested per day were increased by SCFP for lower- producing cows and decreased for higher-producing cows. Opposite interactions were observed for postruminal digestibility and amounts digested per day for OM ( $P<0.04$ quadratic); SCFP increased postruminal OM digestibility and digested amounts per day for cows with higher DMI, but decreased them for cows with lower DMI (Table 9). Compensatory digestion of OM postruminally resulted in a slight increase in total-tract OM digestibility for SCFP compared with CON, with a greater difference as pDMI increased (interaction $P$ $=0.04$ linear; Table 9). Figure 3 shows the interactions between treatment and pDMI for apparent ruminal, postruminal, and total-tract OM digestibility. Similar relationships were observed for true OM digestibility.

The SCFP did not affect $\mathrm{N}$ intake or apparent totaltract $\mathrm{N}$ digestion compared with $\mathrm{CON}$ but interacted with pDMI for apparent total-tract $\mathrm{N}$ digestibility $(P$ $=0.09$ linear; Table 10), with a slight decrease $(<2$ percentage units) for cows with lower pDMI and a slight increase $(<3$ percentage units) for cows with higher pDMI compared with CON. The SCFP increased ruminal ammonia concentration $(P=0.02)$ compared with CON but interacted with pDMI; ruminal ammonia concentration was increased for cows with pDMI in 
Table 8. Starch digestion by cows for Saccharomyces cerevisiae fermentation product (SCFP) and control (CON) treatments and interaction with DMI measured during the preliminary period

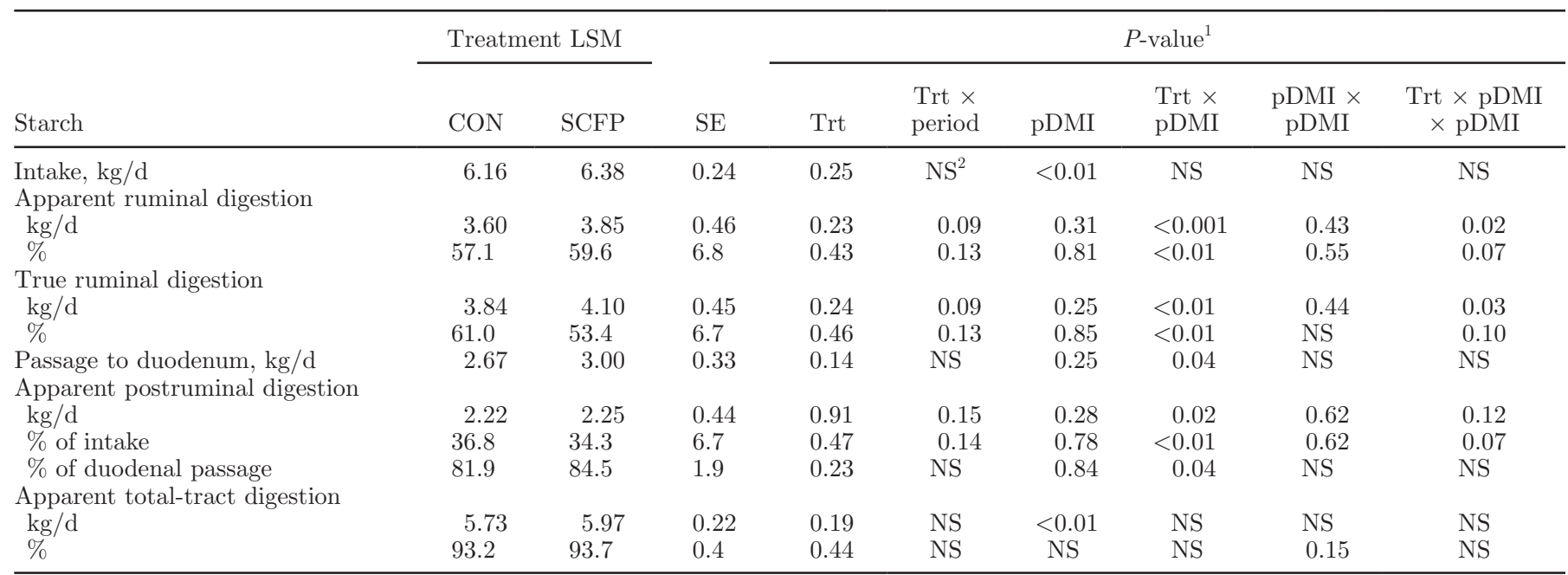

${ }^{1} P$-values for treatment (Trt), Trt by period interaction (Trt $\times$ period), preliminary DMI (pDMI), Trt by pDMI interaction $($ Trt $\times$ pDMI), quadratic effect of $\mathrm{pDMI}(\mathrm{pDMI} \times \mathrm{pDMI})$, and Trt by quadratic effect of $\mathrm{pDMI}($ Trt $\times \mathrm{pDMI} \times \mathrm{pDMI})$.

${ }^{2} \mathrm{NS}=$ nonsignificant, with $P>0.15$; term was removed from the statistical model. Linear and quadratic effects of pDMI were removed from the model if their corresponding interactions with Trt were removed, although $P$-values are included in the table.

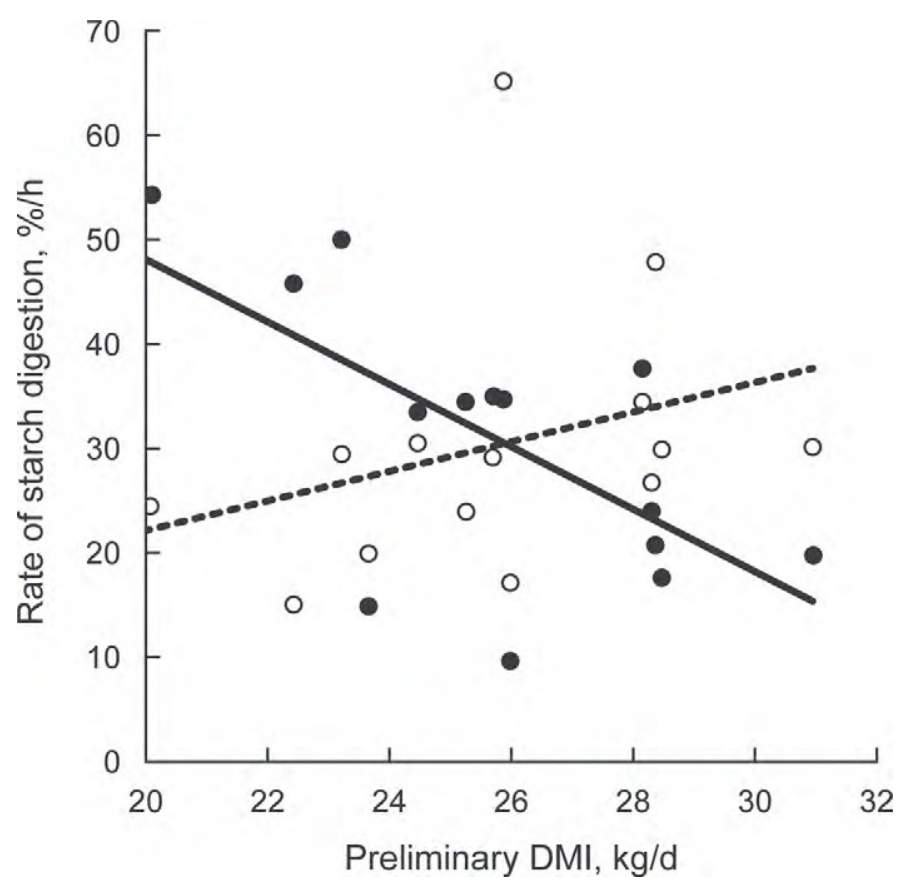

Figure 2. Interaction of (CON; open circles, dashed line) and Saccharomyces cerevisiae fermentation product (SCFP; closed circles, solid line) with preliminary DMI (pDMI) for rate of starch digestion in the rumen $(P<0.01$ linear $)$. The $\mathrm{pDMI}$ on the $\mathrm{x}$-axis are the mean DMI of individual cows during the final $4 \mathrm{~d}$ of the preliminary period when all cows were fed a common diet. The rate of starch digestion decreased linearly as pDMI increased for $\operatorname{SCFP}(P=0.01)$ but no relationship was observed for $\mathrm{CON}(P=0.26)$. the middle of the range, but decreased for cows with higher and lower DMI $(P<0.01$, quadratic). However, ammonia flow to the duodenum was not affected by treatment. Treatment interacted with pDMI to affect flow of NAN to the duodenum as both amount per day $(P=0.08$ quadratic) and as a percentage of $\mathrm{N}$ intake $(P=0.02$ quadratic), and flow of NANMN as a percentage of $\mathrm{N}$ intake to the duodenum $(P=0.01$ quadratic; Table 10); SCFP reduced flows compared with CON for cows with pDMI in the middle of the range but increased flows compared with $\mathrm{CON}$ for cows with higher and lower DMI. Treatment did not affect the flow of microbial $\mathrm{N}$ to the duodenum but tended to interact with pDMI to affect efficiency of microbial $\mathrm{N}$ production (MNE), measured as microbial $\mathrm{N}$ flow per kilogram of true ruminally degraded $\mathrm{OM}(P=0.11$ quadratic; Table 10). The SCFP treatment increased MNE for cows with higher DMI and decreased MNE for cows with lower DMI compared with CON. The SCFP interacted with pDMI to affect postruminal digestibility of NAN as a percentage of NAN flow to the duodenum ( $P=0.04$ quadratic), decreasing digestibility for cows with DMI in the midrange and increasing digestibility for cows with higher or lower DMI. This, and the interaction between treatment and pDMI for NAN flow to the duodenum, resulted in a similar interaction between treatment and pDMI for postruminal digestion of NAN as both amount $(P=0.03$ quadratic $)$ and as a percentage of $\mathrm{N}$ intake $(P=0.02$ quadratic).

No effect of treatment was observed for ruminal $\mathrm{pH}$, concentration of total VFA, propionate, butyrate, val- 
Table 9. Dry matter and OM digestion by cows for Saccharomyces cerevisiae fermentation product (SCFP) and control (CON) treatments and interaction with DMI measured during the preliminary period

\begin{tabular}{|c|c|c|c|c|c|c|c|c|c|}
\hline Item & \multicolumn{2}{|c|}{ Treatment LSM } & SE & \multicolumn{6}{|c|}{$P$-value ${ }^{1}$} \\
\hline Intake, $\mathrm{kg} / \mathrm{d}$ & 22.4 & 23.2 & 0.8 & 0.27 & $\mathrm{NS}^{3}$ & $<0.01$ & NS & NS & NS \\
\hline \multicolumn{10}{|l|}{ Apparent total-tract digestion } \\
\hline $\mathrm{kg} / \mathrm{d}$ & 14.1 & 14.7 & 0.5 & 0.14 & NS & $<0.0001$ & NS & NS & NS \\
\hline Intake, $\mathrm{kg} / \mathrm{d}$ & 18.7 & 19.3 & 0.7 & 0.28 & NS & $<0.01$ & NS & NS & NS \\
\hline \multicolumn{10}{|l|}{ Apparent ruminal digestion } \\
\hline $\mathrm{kg} / \mathrm{d}$ & 4.35 & 5.25 & 0.72 & 0.12 & NS & 0.87 & 0.05 & 0.91 & 0.02 \\
\hline$\%$ & 23.2 & 27.5 & 3.5 & 0.12 & NS & 0.38 & 0.06 & 0.99 & 0.02 \\
\hline \multicolumn{10}{|l|}{ True ruminal digestion } \\
\hline $\mathrm{kg} / \mathrm{d}$ & 8.30 & 9.32 & 0.64 & 0.08 & NS & 0.16 & 0.14 & 0.72 & 0.08 \\
\hline$\%$ & 44.5 & 48.4 & 2.8 & 0.09 & NS & 0.50 & 0.15 & 0.80 & 0.06 \\
\hline $\mathrm{kg} / \mathrm{d}$ & 11.1 & 11.7 & 0.4 & 0.13 & NS & $<0.01$ & NS & NS & NS \\
\hline$\%$ & 59.8 & 60.7 & 0.4 & 0.08 & NS & 0.32 & 0.04 & 0.09 & NS \\
\hline
\end{tabular}

${ }^{1} P$-values for treatment (Trt), Trt by period interaction $($ Trt $\times$ period), preliminary DMI $(\mathrm{pDMI})$, Trt by pDMI interaction $($ Trt $\times \mathrm{pDMI})$, quadratic effect of $\mathrm{pDMI}(\mathrm{pDMI} \times \mathrm{pDMI})$, and Trt by quadratic effect of $\mathrm{pDMI}($ Trt $\times \mathrm{pDMI} \times \mathrm{pDMI})$.

${ }^{2}$ Determined using $105^{\circ} \mathrm{C} \mathrm{DM}$.

${ }^{3} \mathrm{NS}=$ nonsignificant, with $P>0.15$; term was removed from the statistical model. Linear and quadratic effects of pDMI were removed from the model if their corresponding interactions with Trt were removed, although $P$-values are included in the table.

erate, or lactate (Table 11). However, SCFP tended to decrease concentration of isobutyrate (1.21 vs. 1.29 $\mathrm{m} M, P=0.10)$ and increased ruminal acetate concentration for cows with midrange DMI and decreased it for cows with higher or lower DMI compared with CON $(P=0.03$ quadratic). The SCFP also decreased concentrations of isovalerate and total branched-chain VFA compared with CON throughout the range in DMI but had less effect for cows with DMI in the middle of the range $(P<0.10$ quadratic for both). The SCFP had little effect on milk FA profile (data not shown) and did not affect or interact with pDMI to affect specific FA of interest (Table 12).

The SCFP had no effect on measures of energy intake, partitioning, or efficiency of energy utilization, except for an interaction with pDMI for total-tract GE digestibility $(P=0.03$ linear; Table 13$)$. However, the difference in digestibility was very small $(<0.5$ percentage units) throughout the range in pDMI.

\section{DISCUSSION}

The most notable response observed in this experiment was the interaction between treatment and pDMI for rate of starch digestion in the rumen and its subsequent effect on apparent and true ruminal starch digestibility. This is a novel finding and might explain variation in production response to treatment among experiments reported in the literature. For instance, in our previous study (Longuski et al., 2009), SCFP prevented a decrease in milk fat yield of high-producing cows $(\sim 43 \mathrm{~kg} / \mathrm{d})$ when challenged by a highly fermentable starch source. Whereas the fermentable starch challenge decreased FCM and milk fat yields for the CON diet, a reduction in ruminal starch digestibility by SCFP might have allowed cows to benefit from the fermentable starch challenge.

We previously showed that increased ruminal starch digestibility can reduce DMI (Oba and Allen, 2003a; Bradford and Allen, 2004) by reducing meal size (Oba and Allen, 2003a). This reduction in DMI is likely related to increased propionate production in the rumen from greater starch digestion because propionate has been shown to be hypophagic in ruminants compared with other absorbed fuels (Allen, 2000). We hypothesize that the mechanism is related to stimulation of hepatic oxidation from increased propionate flux to the liver during meals, resulting in a satiety signal when diets contain more ruminally degraded starch (Allen et al., 2009). Although DMI was not affected by treatment in this experiment, the interaction of SCFP and pDMI for ruminal starch digestion might explain the interaction observed for intermeal interval. Greater ruminal starch digestibility for cows with lower pDMI, likely 

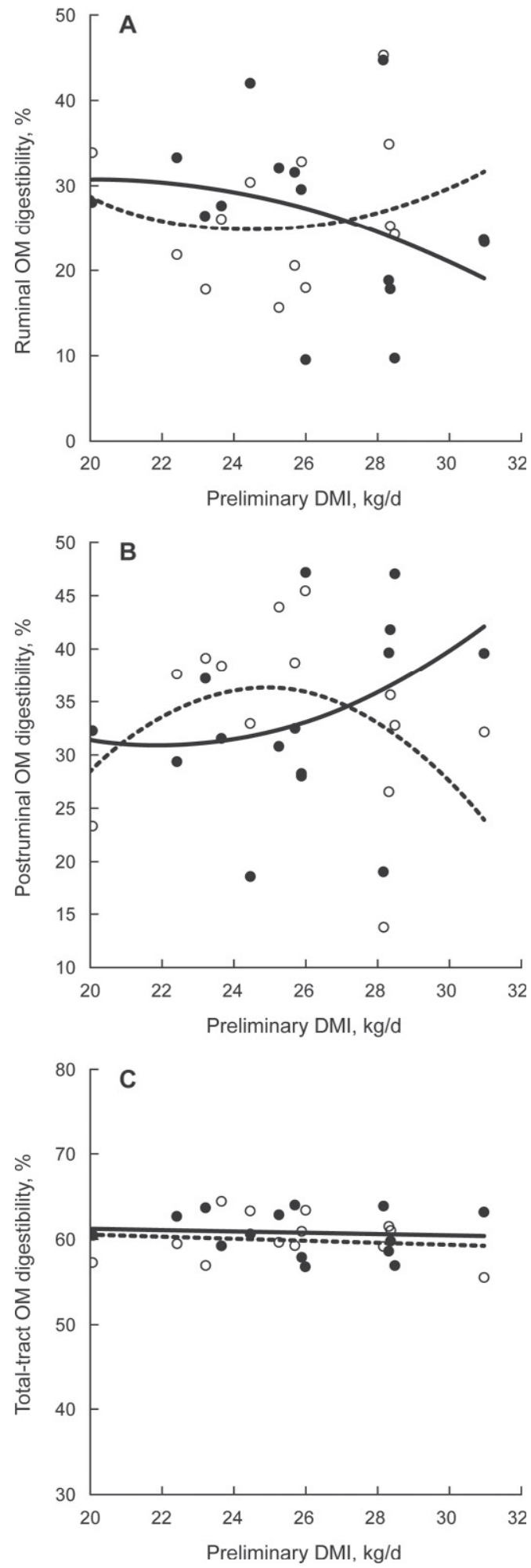

Figure 3. Interaction of control (CON; open circles, dashed line) and Saccharomyces cerevisiae fermentation product (SCFP; closed circles, solid line) with preliminary DMI (pDMI) for apparent digestibility of OM: $(\mathrm{A})$ ruminal $(P=0.02$ quadratic $),(\mathrm{B})$ postruminal $(P$ $=0.01$ quadratic $)$, and $(\mathrm{C})$ total tract $(P=0.04$ linear $)$. The $\mathrm{pDMI}$ on the $\mathrm{x}$-axis are the mean DMI of individual cows during the final $4 \mathrm{~d}$ of the preliminary period when all cows were fed a common diet. increased propionate flux to the liver during and after meals, possibly increasing the interval between meals. Conversely, lower ruminal starch digestibility for cows with greater pDMI likely decreased propionate flux to the liver during and after meals, possibly decreasing the interval between meals. Meal size was not measured but no effect of treatment on calculated daily mean meal size was observed (data not shown). Although an interaction between SCFP and pDMI was not detected for ruminal propionate concentration, ruminal VFA concentration is not a predictor of rate of production and absorption (Oba and Allen, 2003a) and it is likely that greater ruminal starch digestion resulted in greater production and absorption of propionate (Sutton et al., 2003). Failure to detect an interaction between SCFP and $\mathrm{pDMI}$ for DMI might be because different mechanisms affected DMI among the cows in this experiment; ruminal distention becomes a more dominant mechanism affecting DMI as milk yield and DMI increase and oxidation of fuels likely dominates for cows with lower nutrient demand (Allen, 2000; Voelker et al., 2002). The interaction of SCFP and pDMI on ruminal starch digestion and intermeal interval in the present experiment is consistent with the observation by Erasmus et al. (2005) that DMI response to SCFP treatment increased with DMI among cows in that experiment; SCFP depressed DMI compared with CON for cows with lower DMI and increased DMI compared with $\mathrm{CON}$ for cows with higher DMI. Greater ruminal starch digestion among cows with lower intake combined with greater dominance of hepatic oxidation for control of DMI might have caused this response.

Saccharomyces cerevisiae fermentation product has been reported to stimulate growth of fiber-degrading bacteria (Wiedmeier et al., 1987; Harrison et al., 1988; Callaway and Martin, 1997) and increase digestibility of fiber both in situ (Yoon and Garrett, 1998), and in vivo (Wiedmeier et al., 1987). However, SCFP did not affect ruminal digestibility, turnover, or pool size of NDF, a potential mechanism by which SCFP might increase DMI (Oba and Allen, 1999b). Total-tract NDF digestibility was relatively low, likely because the forages were highly lignified (diet lignin $\sim 12 \%$ of NDF; Table 2).

Saccharomyces cerevisiae fermentation product has been reported to increase populations of lactate-degrading organisms (Nisbet and Martin, 1991), potentially increasing ruminal $\mathrm{pH}$. However, treatment did not affect ruminal concentration of lactate or mean ruminal $\mathrm{pH}$ in this experiment. The lack of effect of SCFP on ruminal $\mathrm{pH}$ is consistent with the complete absence of effects of treatment on responses affected by ruminal $\mathrm{pH}$, such as ruminal digestion of NDF, milk FA profile, milk fat yield, and energy partitioning. Daily mean 
Table 10. Nitrogen metabolism of cows for Saccharomyces cerevisiae fermentation product (SCFP) and control (CON) treatments and interaction with DMI measured during the preliminary period

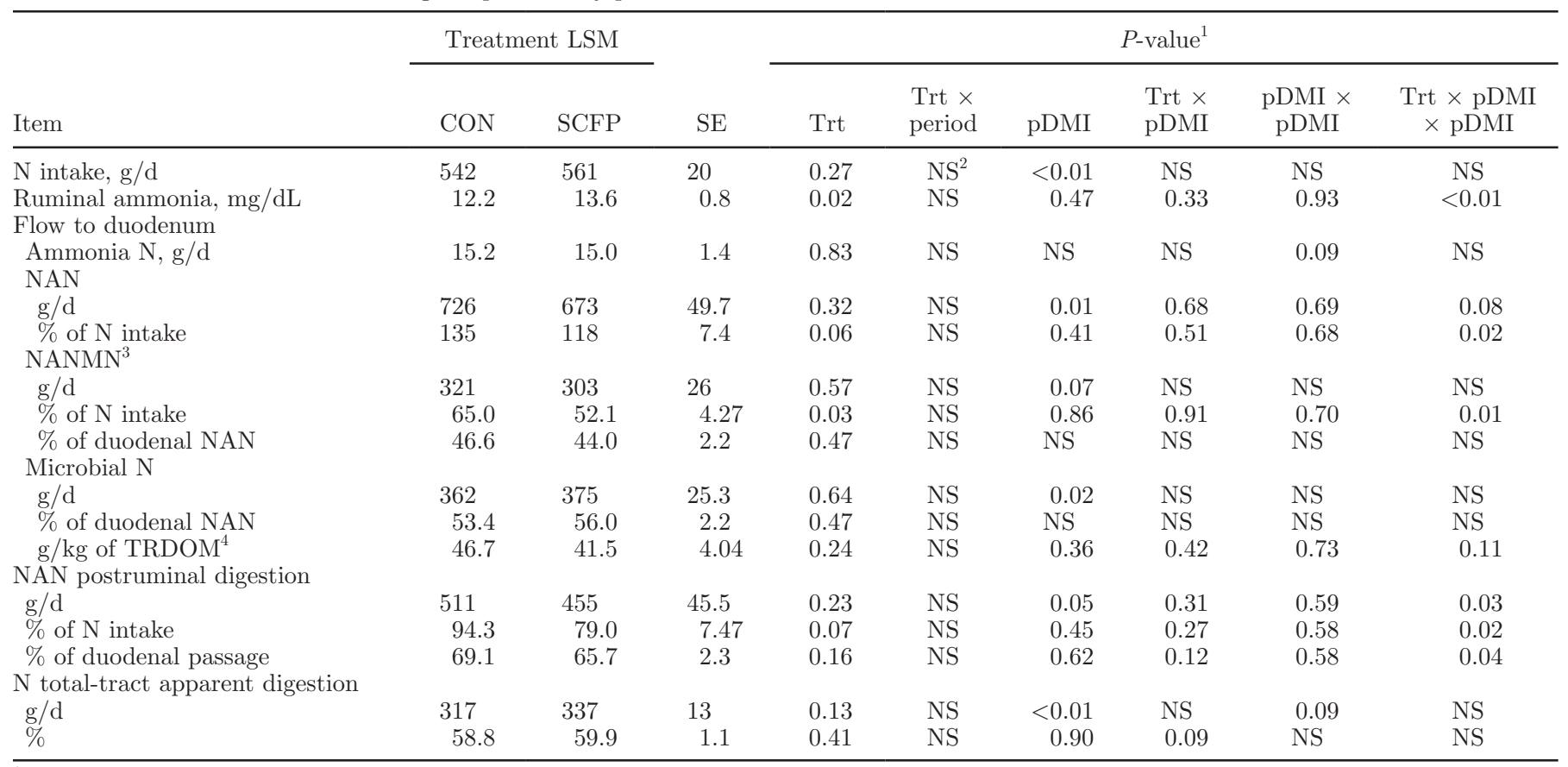

${ }^{1} P$-values for treatment (Trt), Trt by period interaction (Trt $\times$ period), preliminary DMI (pDMI), Trt by pDMI interaction $($ Trt $\times$ pDMI), quadratic effect of $\mathrm{pDMI}(\mathrm{pDMI} \times \mathrm{pDMI})$, and Trt by quadratic effect of $\mathrm{pDMI}($ Trt $\times \mathrm{pDMI} \times \mathrm{pDMI})$.

${ }^{2} \mathrm{NS}=$ nonsignificant, with $P>0.15$; term was removed from the statistical model. Linear and quadratic effects of pDMI were removed from the model if their corresponding interactions with Trt were removed, although $P$-values are included in the table.

${ }^{3} \mathrm{NANMN}=$ nonammonia, nonmicrobial $\mathrm{N}$.

${ }^{4} \mathrm{TRDOM}=$ true ruminally digested OM.

ruminal $\mathrm{pH}$ was positively related to digestion rate of pdNDF (Oba and Allen, 2003b) and a reduction in $\mathrm{pH}$ is the main cause of altered biohydrogenation of FA by rumen microbes (Fuentes et al., 2009), resulting in milk fat depression. Further, certain trans FA produced by ruminal biohydrogenation can alter energy partitioning (Harvatine et al., 2009).

All interactions observed between treatment and pDMI for nitrogen metabolism in the rumen and postruminal digestion were quadratic; for cows with higher and

Table 11. Ruminal VFA concentrations and $\mathrm{pH}$ of cows for Saccharomyces cerevisiae fermentation product (SCFP) and control (CON) treatments and interaction with DMI measured during the preliminary period

\begin{tabular}{|c|c|c|c|c|c|c|c|c|c|}
\hline Item & \multicolumn{2}{|c|}{ Treatment LSM } & SE & \multicolumn{6}{|c|}{$P$-value ${ }^{1}$} \\
\hline Acetate & 80.8 & 82.2 & 1.9 & 0.15 & NS & 0.66 & 0.97 & 0.81 & 0.03 \\
\hline Propionate & 36.1 & 34.7 & 1.74 & 0.74 & NS & NS & NS & NS & NS \\
\hline Butyrate & 20.3 & 20.2 & 0.7 & 0.89 & NS & NS & NS & 0.13 & NS \\
\hline Branched-chain VFA & 3.71 & 3.67 & 0.20 & 0.79 & NS & 0.92 & 0.42 & 0.39 & 0.08 \\
\hline Lactate, $\mathrm{m} M$ & 0.70 & 0.92 & 0.22 & 0.51 & NS & NS & NS & 0.11 & NS \\
\hline Acetate:propionate & 2.35 & 2.34 & 0.13 & 0.90 & NS & NS & NS & NS & NS \\
\hline Ruminal pH & 5.96 & 5.97 & 0.05 & 0.74 & NS & NS & NS & 0.08 & NS \\
\hline
\end{tabular}

${ }^{1} P$-values for treatment $($ Trt $)$, Trt by period interaction $($ Trt $\times$ period), preliminary DMI $(\mathrm{pDMI})$, Trt by pDMI interaction $($ Trt $\times$ pDMI), quadratic effect of pDMI $(\mathrm{pDMI} \times \mathrm{pDMI})$, and Trt by quadratic effect of $\mathrm{pDMI}($ Trt $\times \mathrm{pDMI} \times \mathrm{pDMI})$.

${ }^{2} \mathrm{NS}=$ nonsignificant, with $P>0.15$; term was removed from the statistical model. Linear and quadratic effects of pDMI were removed from the model if their corresponding interactions with Trt were removed, although $P$-values are included in the table. 
Table 12. Milk FA profile for cows for Saccharomyces cerevisiae fermentation product (SCFP) and control (CON) treatments and interaction with DMI measured during the preliminary period

\begin{tabular}{|c|c|c|c|c|c|c|c|c|c|}
\hline \multirow[b]{2}{*}{ FA, $\%$ of total } & \multicolumn{2}{|c|}{ Treatment LSM } & \multirow[b]{2}{*}{$\mathrm{SE}$} & \multicolumn{6}{|c|}{$P$-value ${ }^{1}$} \\
\hline & $\mathrm{CON}$ & SCFP & & Trt & $\begin{array}{l}\text { Trt } \times \\
\text { period }\end{array}$ & $\mathrm{pDMI}$ & $\begin{array}{l}\text { Trt } \times \\
\text { pDMI }\end{array}$ & $\begin{array}{c}\mathrm{pDMI} \times \\
\mathrm{pDMI}\end{array}$ & $\begin{array}{c}\text { Trt } \times \text { pDMI } \\
\times \text { pDMI }\end{array}$ \\
\hline $\mathrm{CLA}^{3}($ cis-9,trans-11) & 0.56 & 0.54 & 0.041 & 0.68 & NS & 0.11 & NS & NS & NS \\
\hline CLA (trans-10,cis-12) & 0.006 & 0.003 & 0.003 & 0.19 & NS & NS & NS & NS & NS \\
\hline $18: 1$ trans & 4.32 & 3.72 & 0.83 & 0.40 & NS & NS & NS & NS & NS \\
\hline Total C18 & 35.4 & 34.4 & 1.31 & 0.19 & NS & $<0.01$ & NS & NS & NS \\
\hline $\mathrm{Uns}^{4} \mathrm{C} 18$ & 27.5 & 26.3 & 1.28 & 0.13 & NS & 0.06 & NS & NS & NS \\
\hline Uns \% in C18 & 77.3 & 76.2 & 1.26 & 0.26 & NS & NS & NS & NS & NS \\
\hline
\end{tabular}

${ }^{1} P$-values for treatment (Trt), Trt by period interaction (Trt $\times$ period), preliminary DMI $(\mathrm{pDMI})$, Trt by pDMI interaction $($ Trt $\times$ pDMI), quadratic effect of pDMI $(\mathrm{pDMI} \times \mathrm{pDMI})$, and Trt by quadratic effect of $\mathrm{pDMI}($ Trt $\times \mathrm{pDMI} \times \mathrm{pDMI})$.

${ }^{2} \mathrm{NS}=$ nonsignificant, with $P>0.15$; term was removed from the statistical model. Linear and quadratic effects of pDMI were removed from the model if their corresponding interactions with Trt were removed, although $P$-values are included in the table.

${ }^{3}$ Conjugated linoleic acid.

${ }^{4}$ Uns $=$ unsaturated.

lower pDMI compared with cows with midrange pDMI, SCFP decreased ruminal ammonia concentration and increased NAN and NANMN flows to the duodenum as a percentage of $\mathrm{N}$ intake and postruminal digestibility of NAN as a percentage of $\mathrm{N}$ intake compared with CON. A reduction in ruminal ammonia concentration

Table 13. Energy balance and efficiency of cows for Saccharomyces cerevisiae fermentation product (SCFP) and control (CON) treatments and interaction with DMI measured during the preliminary period

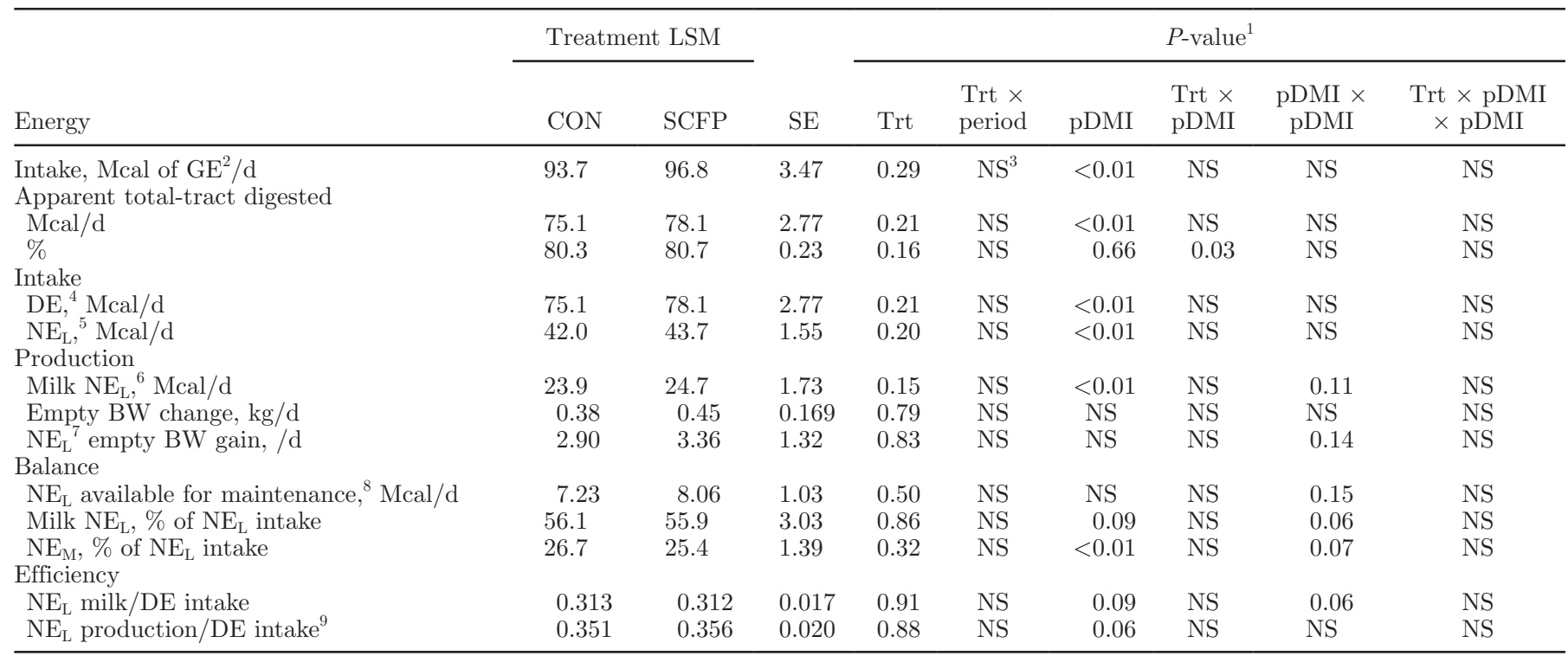

${ }^{1} P$-values for treatment (Trt), Trt by period interaction $($ Trt $\times$ period), preliminary DMI $(\mathrm{pDMI})$, Trt by pDMI interaction $($ Trt $\times \mathrm{pDMI})$ quadratic effect of $\mathrm{pDMI}(\mathrm{pDMI} \times \mathrm{pDMI})$, and Trt by quadratic effect of $\mathrm{pDMI}($ Trt $\times \mathrm{pDMI} \times \mathrm{pDMI})$.

${ }^{2} \mathrm{GE}=$ gross energy

${ }^{3} \mathrm{NS}=$ nonsignificant, with $P>0.15$; term was removed from the statistical model. Linear and quadratic effects of pDMI were removed from the model if their corresponding interactions with Trt were removed, although $P$-values are included in the table.

${ }^{4} \mathrm{DE}=$ digestible energy.

${ }^{5} \mathrm{NE}_{\mathrm{L}(\text { intake })}=\mathrm{DMI}(\mathrm{kg}) \times[0.0245 \times \mathrm{TDN}(\%)](\mathrm{NRC}, 1989)$.

${ }^{6} \mathrm{NE}_{\mathrm{L}(\text { milk })}(\mathrm{Mcal} / \mathrm{d})=$ milk yield $(\mathrm{kg}) \times(0.0929 \times$ fat $\%+0.0563 \times$ true protein $\%+0.0395 \times$ lactose $\%)(\mathrm{NRC}, 2001)$.

${ }^{7} \mathrm{NE}_{\mathrm{L}(\text { empty BW change) }}$ calculated according to NRC (2001).

${ }^{8} \mathrm{NE}_{\mathrm{L}}$ available for maintenance $=\mathrm{NE}_{\mathrm{L} \text { (intake) }}-\mathrm{NE}_{\mathrm{L}(\text { maintenance) }}-\mathrm{NE}_{\mathrm{L}(\text { milk })}$, where $\mathrm{NE}_{\mathrm{L}(\text { maintenance })}=0.080 \times \mathrm{BW}^{0.75}(\mathrm{NRC}, 2001)$.

${ }^{9}\left(\mathrm{NE}_{\mathrm{L}}\right.$ milk yield $+\mathrm{NE}_{\mathrm{L}} \mathrm{BW}$ gain $) / \mathrm{DE}$ intake. 
might be from reduced proteolysis in the rumen, consistent with the corresponding greater duodenal flows of NANMN and NAN. A reduction in proteolysis is more likely for cows with higher pDMI, for which SCFP reduced the rate of starch digestion and ruminal starch digestibility compared with CON, because some starchdegrading bacteria (e.g., Streptococcus bovis) have high proteolytic activity (Russell et al. 1981), resulting in deamination of $\mathrm{AA}$ and production of ammonia. This is also consistent with the observed decrease in ruminal concentration of branched-chain VFA derived from deamination of branched-chain AA. Differences in ruminal ammonia concentration might also have been from incorporation of ammonia into microbial protein, microbial lysis, or predation of bacteria by protozoa. However, no effect of treatment or its interaction with pDMI was detected for duodenal flow of microbial N.

The interaction between treatment and pDMI observed for efficiency of microbial $\mathrm{N}$ production is consistent with the effects of treatment on rate of starch digestion in the rumen. We previously reported negative relationships between MNE and rate of starch digestion (Oba and Allen, 2003c; Voelker and Allen, 2003), indicating that energy from starch fermentation might not be efficiently utilized for microbial growth as rate of starch digestion increases. This might be because of a deficiency of AA, peptides, or any unknown growth factors or because the rate of fermentation exceeded the maximum growth rate of the microbial population (Oba and Allen, 2003c).

\section{CONCLUSIONS}

Ruminal starch digestion response to SCFP varied across cows used in this experiment and the response was related to their daily feed intake. A reduction in rate of starch digestion and ruminal starch digestibility for cows consuming higher quantities of feed might allow lower-forage, higher-starch diets to be fed, decreasing the filling effect of the diet and providing more glucose precursors for these cows with greater glucose requirements. Increased ruminal starch digestibility for cows with lower feed intake might allow lower-starch, higher-forage diets to be fed, possibly reducing diet cost without lowering milk yield. However, greater starch digestibility for lower-producing cows with adipose tissue that is more insulin sensitive might partition more energy to body condition at the expense of milk yield if diets are not formulated to compensate. Further research is needed on the mechanism by which this SCFP affects the populations of starch-digesting microbes in the rumen and its interaction with feed intake.

\section{ACKNOWLEDGMENTS}

This research was partially funded by Diamond $\mathrm{V}$ Mills Inc. (Cedar Rapids, IA). The authors thank N. K. Ames (Department of Large Animal Clinical Science, College of Veterinary Medicine, Michigan State University, East Lansing) for performing duodenal and ruminal cannulation surgeries, Ilkyu Yoon (Diamond V Mills Inc.) and Kim Kammes (Department of Animal Science, Michigan State University) for helpful comments related to the preparation of the manuscript, D. G. Main and R. A. Longuski (Department of Animal Science, Michigan State University), and R. E. Kreft and the staff of the Michigan State University Dairy Cattle Teaching and Research Center (East Lansing) for their technical assistance and support, and West Central Soy (Ralston, IA) for donating the SoyPLUS protein supplement.

\section{REFERENCES}

Allen, M. S. 2000. Effects of diet on short-term regulation of feed intake by lactating dairy cows. J. Dairy Sci. 83:1598-1624.

Allen, M. S., B. J. Bradford, and M. Oba. 2009. Board-invited review: The hepatic oxidation theory of the control of feed intake and its application to ruminants. J. Anim. Sci. 87:3317-3334.

AOAC (Association of Official Analytical Chemists). 1990. Official Methods of Analysis. Vol. 2. 15th ed. AOAC, Arlington, VA.

Bradford, B. J., and M. S. Allen. 2004. Milk fat responses to a change in diet fermentability vary by production level in dairy cattle. J. Dairy Sci. 87:3800-3807.

Broderick, G. A., and J. H. Kang. 1980. Automated simultaneous determination of ammonia and total amino acids in rumen fluid and in vitro media. J. Dairy Sci. 63:64-75.

Callaway, E. S., and S. A. Martin. 1997. Effects of a Saccharomyces cerevisiae culture on ruminal bacteria that utilize lactate and digest cellulose. J. Dairy Sci. 80:2035-2044.

Chouinard, P. Y., L. Corneau, D. M. Barbano, L. E. Metzger, and D. E. Bauman. 1999. Conjugated linoleic acids alter milk fatty acid composition and inhibit milk fat secretion in dairy cows. J. Nutr. 129:1579-1584.

Christie, W. W. 1982. A simple procedure for rapid transmethylation of glycerolipids and cholesteryl esters. J. Lipid Res. 23:1072-1075.

Cochran, R. C., D. C. Adams, J. D. Wallace, and M. L. Galyean. 1986. Predicting digestibility of different diets with internal markers: Evaluation of four potential markers. J. Anim. Sci. 63:1476-1483.

Cochran, R. C., E. S. Vanzant, and T. DelCurto. 1988. Evaluation of internal markers isolated by alkaline hydrogen peroxide incubation and acid detergent lignin extraction. J. Anim. Sci. 66:3245-3251.

Erasmus, L. J., P. H. Robinson, A. Ahmadi, R. Hinders, and J. E. Garrett. 2005. Influence of prepartum and postpartum supplementation of a yeast culture and monensin, or both, on ruminal fermentation and performance of multiparous dairy cows. Anim. Feed Sci. Technol. 122:219-239.

Fuentes, M. C., S. Calsamiglia, P. W. Cardozo, and B. Vlaeminck. 2009. Effect of $\mathrm{pH}$ and level of concentrate in the diet on the production of biohydrogenation intermediates in a dual-flow continuous culture. J. Dairy Sci. 92:4456-4466.

Goering, H. K., and P. J. Van Soest. 1970. Forage Fiber Analysis (Apparatus, Reagents, Procedures, and Some Applications). Agric. Handbook No. 379. Agricultural Research Service-US Department of Agriculture (ARS-USDA), Washington, DC. 
Hach, C. C., B. K. Bowden, A. B. Kopelove, and S. V. Brayton. 1987. More powerful peroxide Kjeldahl digestion method. J. Assoc. Off. Anal. Chem. 70:783-787.

Hara, A., and N. S. Radin. 1978. Lipid extraction of tissues with a low-toxicity solvent. Anal. Biochem. 90:420-426.

Harrison, G. A., R. W. Hemken, K. A. Dawson, R. J. Harmon, and K. B. Barber. 1988. Influence of addition of yeast culture supplement to diets of lactating cows on ruminal fermentation and microbial populations. J. Dairy Sci. 71:2967-2975.

Harvatine, K. J., J. W. Perfield II, and D. E. Bauman. 2009. Expression of enzymes and key regulators of lipid synthesis is upregulated in adipose tissue during CLA-induced milk fat depression in dairy cows. J. Nutr. 139:849-854.

Hristov, A. N., G. Varga, T. Cassidy, M. Long, K. Heyler, S. K. R. Karnati, B. Corl, C. J. Hovde, and I. Yoon. 2010. Effect of Saccharomyces cerevisiae fermentation product on ruminal fermentation and nutrient utilization in dairy cows. J. Dairy Sci. 93:682-692.

Karkalas, J. 1985. An improved enzymatic method for the determination of native and modified starch. J. Sci. Food Agric. 36:10191027.

Longuski, R. A., Y. Ying, and M. S. Allen. 2009. Yeast culture supplementation prevented milk fat depression by a short-term dietary challenge with fermentable starch. J. Dairy Sci. 92:160-167.

Mertens, D. R. 2002. Gravimetric determination of amylase-treated neutral detergent fiber in feeds using refluxing in beakers or crucibles: Collaborative study. J. AOAC Int. 85:1217-1240.

Nisbet, D. J., and S. A. Martin. 1991. Effect of a Saccharomyces cerevisiae culture on lactate utilization by the ruminal bacterium Selenomonas ruminantium. J. Anim. Sci. 69:4628-4633.

NRC. 1989. Nutrient Requirements of Dairy Cattle. 6th ed. Natl. Acad. Sci., Washington, DC.

NRC. 2001. Nutrient Requirements of Dairy Cattle. 7th ed. Natl. Acad. Sci., Washington, DC.

Oba, M., and M. S. Allen. 1999a. Effects of brown midrib 3 mutation in corn silage on dry matter intake and productivity of high yielding dairy cows. J. Dairy Sci. 82:135-142.

Oba, M., and M. S. Allen. 1999b. Evaluation of the importance of the digestibility of neutral detergent fiber from forage: Effects on dry matter intake and milk yield of dairy cows. J. Dairy Sci. 82:589-596.

Oba, M., and M. S. Allen. 2003a. Effects of corn grain conservation method on feeding behavior and productivity of lactating dairy cows at two dietary starch concentrations. J. Dairy Sci. 86:174183.

Oba, M., and M. S. Allen. 2003b. Effects of corn grain conservation method on ruminal digestion kinetics for lactating dairy cows at two dietary starch concentrations. J. Dairy Sci. 86:184-194.

Oba, M., and M. S. Allen. 2003c. Effects of diet fermentability on efficiency of microbial nitrogen production in lactating dairy cows. J. Dairy Sci. 86:195-207.
Rabiee, A.R., I. J. Lean, K.L. Dorton, M.E. Engstrom, and W.K. Sanchez. 2008. Effect of feeding Diamond V Yeast Culture ${ }^{\mathrm{TM}}$ on milk production and dry matter intake in lactating dairy cows: A meta-analysis. J. Dairy Sci. 91(E-Suppl. 1):589-590.

Russell, J. B., W. G. Bottje, and M. A. Cotta. 1981. Degradation of protein by mixed cultures of rumen bacteria: Identification of Streptococcus bovis as an actively proteolytic rumen bacterium. J. Anim. Sci. 53:242-252.

Sutton, J. D., M. S. Dhanoa, S. V. Morant, J. France, D. J. Napper, and E. Schuller. 2003. Rates of production of acetate, propionate, and butyrate in the rumen of lactating dairy cows given normal and low-roughage diets. J. Dairy Sci. 86:3620-3633.

Voelker, J. A., and M. S. Allen. 2003. Pelleted beet pulp substituted for high-moisture corn: 3. Effects of ruminal fermentation, $\mathrm{pH}$, and microbial protein efficiency in lactating dairy cows. J. Dairy Sci. 86:3562-3570.

Voelker, J. A., G. M. Burato, and M. S. Allen. 2002. Effects of pretrial milk yield on responses of feed intake, digestion, and production to dietary forage concentration. J. Dairy Sci. 85:2650-2661.

Voelker Linton, J. A., and M. S. Allen. 2008. Nutrient demand interacts with forage family to affect intake and digestion responses in dairy cows. J. Dairy Sci. 91:2694-2701.

Weimer, P. J., G. C. Waghorn, C. L. Odt, and D. R. Mertens. 1999. Effect of diet on populations of three species of ruminal cellulolytic bacteria in lactating dairy cows. J. Dairy Sci. 82:122-134.

Wiedmeier, R. D., M. J. Arambel, and J. L. Walters. 1987. Effect of yeast culture and Aspergillus oryzae fermentation extract on ruminal characteristics and nutrient digestibility. J. Dairy Sci. 70:2063-2068

Wildman, E. E., G. M. Jones, P. E. Wagner, R. L. Boman, H. F. Troutt Jr., and T. N. Lesch. 1982. A dairy cow body condition scoring system and its relationship to selected production characteristics. J. Dairy Sci. 65:495-501.

Williams, C. H., D. J. David, and O. Iismaa. 1962. The determination of chromic oxide in feces samples by atomic absorption spectrophotometry. J. Agric. Sci. 59:381-385.

Yoon, I., and J. E. Garrett. 1998. Yeast culture and processing effects on 24-hour in situ ruminal degradation of corn silage. Proc. 8th World Conf. Anim. Prod., Seoul, Korea. Vol. 1:322-323. Seoul National University, Seoul, Korea.

Yoon, I. K., and M. D. Stern. 1996. Effects of Saccharomyces cerevisiae and Aspergillus oryzae cultures on ruminal fermentation in dairy cows. J. Dairy Sci. 79:411-417.

Zinn, R. A., and F. N. Owens. 1986. A rapid procedure for purine measurement and its use for estimating net ruminal protein synthesis. Can. J. Anim. Sci. 66:157-166. 